\title{
A região de aprendizagem como temática e ângulo de observação
}

\section{Palauras-chave \\ aprendizagem, inovação, Santa Catarina, produção têxtil-vestuarista, produção ceramista.}

Classificação JEL L23, O18, O31.

\footnotetext{
Key words

learning, innovation, Santa Catarina, textile and clothing
} production, ceramics production.

JEL Classification L23, O18, 031 .

\section{Resumo}

Os desafios associados às mudanças econômicas recentes ampliaram a importância da aprendizagem e da inovação para o desempenho industrial e o desenvolvimento econômico. De fato, em diferentes realidades, os problemas relacionados a esses processos, considerados coletivos e interativos, passaram a figurar no centro das atenções das políticas. Noção de destaque no debate atual sobre inovação e competitividade é a de região de aprendizagem, que remete ao problema do enraizamento territorial dos processos de aprendizagem coletiva organizados institucionalmente. Este artigo focaliza a idéia de região de aprendizagem, apreendida conforme o esboço trazido pela literatura que se baseia em casos de sucesso no capitalismo central, utilizando-a como "chave de leitura" sobre experiências de aglomerações industriais de Santa Catarina: o Médio Vale do Itajaí, importante área de produção têxtil e vestuarista, e o Sul catarinense, envolvido na fabricação de cerâmica de revestimento, um dos principais aglomerados dessa indústria no País.
Hoyêdo Nunes Lins Professor do Departamento de Ciências Econômicas da Universidade Federal de Santa Catarina

\section{Abstract}

The challenges related to the recent economic changes increased the importance of learning and innovation to both industrial performance and economic development. Indeed, in different contexts policies have become more and more concerned with learning and innovation, seen as collective and interactive processes. The notion of learning region, by which the issue of territorial embeddedness of the processes of institutionally organized collective learning is addressed, emerges as an important theme in the present debate on innovation and competitiveness. This article focuses the idea of learning region, outlined in the literature based on the observation of successful cases in the core of world capitalism, taking it as a sort of guide for examining the experiences of two industrial clusters in Santa Catarina: the Medium Itajai Valley, a well known area of textile and clothing production, and the southern part of this state, one of the most important ceramics producing areas in the whole country. 


\section{1_Introdução}

Os desafios representados pelas mudanças econômicas das últimas décadas, refletidas em grandes avanços tecnológicos e em forte intensificação da concorrência, impuseram a capacidade de inovar como um requisito básico para o desempenho competitivo e, de uma forma ampla, para o desenvolvimento. É, de fato, sugestivo que promover inovações tenha se constituído em medida proeminente (talvez a de maior realce) nas políticas implementadas em diferentes realidades nacionais e regionais, conforme observado no mosaico social, econômico e político da União Européia (Bianchi, 1997). Esse contexto registrou a emergência, no debate sobre a dimensão territorial do desenvolvimento, da noção de região de aprendizagem (learning region). Disseminada desde a segunda metade dos anos 90, essa noção implica considerar como articulados os processos de inovação, difusão de conhecimento, aprendizagem, interações e funcionamento do tecido institucional, todos de grande realce no referido debate.

A idéia de região de aprendizagem figura no centro deste trabalho, que almeja apresentar e discutir a correspondente problemática. A abordagem combina sistematização de bibliografia relevante e observação de aspectos da estrutura so- cioprodutiva do Estado de Santa Catarina à luz da discussão em foco. Baseada em pesquisa de campo própria e em material produzido por outros investigadores, a observação sobre Santa Catarina refere-se às atividades de produção têxtil-vestuarista e produção cerâmica (cerâmica branca, de revestimento) instaladas no Médio Vale do Itajaí e no Sul do território catarinense, pela ordem. Essas atividades, cabe ressaltar, lograram projeção que ultrapassa em muito a órbita regional, marcando presença até em mercados externos tendo em vista o desempenho exportador.

A próxima parte do artigo contém uma aproximação à idéia de região de aprendizagem, e as duas partes seguintes tratam da indústria têxtil-vestuarista do Médio Vale do Itajaí e da indústria ceramista do Sul de Santa Catarina, nessa seqüência; a última seção expõe as considerações finais.

\section{2_O imperativo do conhecimento e da inovação: rumo à idéia de "região de aprendizagem"}

Região de aprendizagem é noção pertencente a campo temático ao qual se atribui grande importância às inovações e ao papel desempenhado pelo espaço como 
1 "Por aumento da força produtiva ou da produtividade do trabalho, entendemos, em geral, uma mudança nos seus procedimentos (...)” (Marx, 1982, p. 306). “A indústria moderna não considera e não trata jamais como definitivo o modo atual de um procedimento. Sua base é, portanto, revolucionária (...). Por meio de máquinas, procedimentos químicos e outros métodos, ela subverte, com a base técnica da produção, as funções dos trabalhadores e as combinações sociais do trabalho, cuja divisão estabelecida ela não cessa de revolucionar (...)" (Marx, 1982, p. 464). "nutriente" dos processos de aprendizagem e "lubrificante" da difusão de conhecimento.

\section{1_ Inovação e "economia de aprendizagem"}

O realce do caráter estratégico das inovações na atualidade é passo importante na aproximação à idéia de região de aprendizagem. Referir às "inovações na atualidade" não significa, todavia, entender que inovar se tornou procedimento estratégico só nas últimas décadas. Toda a trajetória do capitalismo é permeada e pontuada por essa prática. Marx situou-a no âmago do desenvolvimento das forças produtivas, ${ }^{1}$ considerando-a um elemento-chave da concorrência

a determinação do valor pelo tempo de trabalho se impõe como lei ao capitalista que emprega procedimentos aperfeicoados [e] (...) se impõe a seus rivais, como lei coercitiva da concorrência, forçando-os a adotar o novo modo de produção (Marx, 1982, p. 310).

E Schumpeter assimilou-a ao próprio processo de desenvolvimento, amplamente falando

o desenvolvimento, no sentido que lhe damos, é definido (...) pela realização de novas combinações [de meios produtivos] (Schumpeter, 1988, p. 48).
Contudo, é principalmente nos dias atuais, em que o caráter mundial de muitos processos econômicos representa novos desafios para firmas, setores produtivos e estruturas econômicas nacionais e regionais, que inovar se mostra atividade realmente primordial. No mesmo diapasão, aparecem também como imprescindíveis os instrumentos que sustentam e estimulam a produção e disseminação do conhecimento e a aprendizagem. Esses representam suporte para a inovação e, por conseguinte, constituem um recurso essencial na economia moderna. Tudo isso é sintetizado por Lundvall e Borrás (1997) como segue:

A grande importância da inovação espeIha o fato de que esta representa uma resposta de vulto à crescente concorrência, por meio da promoção das habilidades de firmas e trabalhadores para aprender. Nem firmas nem regiões podem se engajar em crescimento sustentável sem inovação e aprendizagem (Lundvall e Borrás, 1997, p. 14).

Note-se que a ênfase na importância da aprendizagem e da criação/ difusão de conhecimento não se vincula somente aos desafios da chamada globalização. Hudson (1999) assinala ser generalizado o entusiasmo - para esse autor, excessivo - com as possibilidades associadas a tais processos. O otimismo é 
perceptível, por exemplo, em relação às promessas de novas e mais ricas formas de organização do trabalho (fruto, justamente, da difusão de conhecimento e da aprendizagem), em contraste com o padrão taylorista-fordista, e também em relação às chances de um desenvolvimento econômico menos marcado por desigualdades, assim como aos acenos de recuperação de cidades e regiões estagnadas ou em declínio. De todo modo, é reconhecido na literatura que as políticas de inovação são essenciais e que o estímulo e o apoio à aprendizagem são elementos centrais de tais políticas. Comungar esse tipo de visão significa atribuir grande importância aos imperativos do que se entende por economia de aprendizagem (learning economy), quer dizer,

uma economia em que a habilidade para aprender é crucial para o sucesso econômico de indivíduos, regiões e economias nacionais. 'Aprendizagem' refere-se à construção de novas competências e ao estabelecimento de novas habilidades, e não somente a 'ter acesso às informações' (Lundvall e Borrás, 1997, p. 35).

Inovação, conhecimento e aprendizagem compõem, como se observa, elenco de questões fundamentais à reflexão sobre competitividade e desenvolvimento e à formulação e implementação das correspondentes políticas de apoio e fortalecimento. Em que medida o espaço pode ser considerado um ingrediente básico dessa problemática, assentada no tripé inovação-conhecimento-aprendizagem?

\section{2_Espaço, aprendizagem e inovação}

Seja na reflexão sobre competitividade e desenvolvimento, seja no tocante à proposição de políticas relacionadas, detecta-se na literatura o entendimento de que o espaço - assimilado à proximidade entre agentes econômicos, com as sinergias potencialmente derivadas, e à "herança" que os territórios concentram e transmitem - é essencial aos processos de aprendizagem e inovação. O raciocínio subjacente envolve considerar a dupla natureza do conhecimento (os aspectos codificado e tácito) e as vantagens da proximidade ligadas, entre outras coisas, às externalidades, aos menores custos e à maior fluidez das diversas inter-relações (entre clientes e fornecedores e entre firmas e instituições, por exemplo).

O conhecimento codificado (entre cujas ilustrações está aquele transmitido por patentes e por máquinas e equipamentos) é de difusão e acesso mais fáceis, e, em virtude disso, não representa aspecto realmente diferenciador de posições na concorrência envolvendo firmas 
ou estruturas econômicas regionais. Já o conhecimento tácito, impregnado nos ambientes produtivos - empresas ou grupos de agentes - e "fixado" em localizações específicas, constitui pilar fundamental da competitividade tendo em vista as "rugosidades" que se interpõem à sua propagação em escala ampla. Ao mesmo tempo, e por conta dessa característica, essa modalidade de conhecimento é um importante fator de diferenciação do espaço. Com efeito,

ao nivel local, onde as firmas compartitham os mesmos valores, o background $e$ a compreensão de problemas técnicos e comerciais, uma certa troca de conbecimento tácito realmente ocorre [...]. Tal habilidade para trocar informações [...] constitui parte importante da vantagem competitiva das aglomerações espaciais de firmas e indústrias relacionadas.

[...]

Desse modo, tanto a formação do mercado mundial como o processo de codificação [do conhecimento] ampliam a importância das capacidades heterogêneas e localizadas para a construção de competências específicas às firmas e, assim, para variações entre firmas no que se refere à sua competitividade (Maskell e Malmberg, 1999, p. 172).

A visão de que a proximidade entre os agentes é decisiva para a difusão do conhecimento e para a dinamização da aprendizagem não é recente. Escrevendo cerca de um século atrás sobre as vantagens da localização de atividades industriais em determinados ambientes, Marshall sublinhava que, nas áreas de produção especializada ou conexa,

os mistérios dos negócios deixam de ser mistérios; são como se estivessem no ar, e as crianças aprendem muitos deles inconscientemente (Marshall, 1979, p. 225).

Não obstante, é particularmente manifesta na atualidade a percepção de que a escala local-regional, propícia a intensas relações face a face e à propagação do conhecimento, configura terreno fértil para a aprendizagem e a inovação. Para Lundvall e Borrás (1997), por exemplo, a

escala geográfica é crucial na economia de aprendizagem. [...] [T]erritório e proximidade desempenham um papel central na gênese do conbecimento tácito e na capacidade para explorá-lo (Lundvall e Borrás, 1997, p. 39).

E Sweeney (1995) é enfático ao afirmar que a

inovação é um fenômeno local/ regional e [que] os sistemas de inovação mais eficientes, dinâmicos e empreendedores são regionais e não nacionais (Sweeney, 1995, p. 35).

Diferentes estudos sugerem, de fato, ser elevada a importância das externalidades de conhecimento nos proces- 
sos de concentração geográfica da produção industrial, formando clusters, $^{2} \mathrm{em}$ especial no que concerne ao desenvolvimento de inovações. $\mathrm{Na}$ base figura o reconhecimento de que o dinamismo das aglomerações tende a ser "alimentado" pela concentração espacial de atividades de pesquisa e desenvolvimento, de mão-de-obra qualificada e de atividades ligadas à ciência básica, entre outros atributos que proporcionam difusão de conhecimentos através de, por exemplo, de spillovers (Audretsch e Feldman, 1996). De todo modo, em que pese essa compreensão, é importante considerar que as características internas das firmas têm grande importância nas atividades inovadoras, revelando capacidade de determinação até maior, muitas vezes, do que a representada pelos traços próprios dos locais ou regiões (Koschatzky, 1998).

Essencial à difusão do conhecimento, à aprendizagem e ao desempenho inovador é a existência de vínculos cooperativos, principalmente entre firmas. ${ }^{3}$ Daí a importância das redes de agentes, em cujo interior vicejam e se fortalecem os sentidos de confiança mútua, reciprocidade, inclinação à aprendizagem coletiva e o compartilhamento de princípios e regras. Ora, o plano localregional representa escala privilegiada para o surgimento e a evolução dessas interações, mesmo que em diferentes experiências se note que as redes transbordam esse nível de vínculos. Portanto, também no que concerne às inter-relações cooperativas, é inequívoca a centralidade do espaço: a proximidade entre os atores favorece e potencializa as interações que forçosamente perpassam os processos de aprendizagem e inovação.

\section{3_A idéia de "região de aprendizagem"}

Aprendizagem e inovação são processos freqüentemente escorados e impulsionados pelo funcionamento de instituições. A própria cooperação entre os agentes, vetor de aprendizagem que lubrifica a inovação, costuma ter na estrutura institucional uma importante base de apoio. Dessa maneira, uma região revela-se mais propícia à ocorrência de inovações na medida em que registra forte presença de aprendizagem coletiva institucionalmente organizada. Numa palavra, quando admite a caracterização de região de aprendizagem (Landabaso, Oughtone e Morgan, 1999).

Glasmeier (1999) assinala que as regiões com esse perfil possuem traços específicos e positivamente diferenciados quanto à presença de recursos intangíveis, à "espessura institucional" e ao grau de inter-relações não mercantis. São
Cluster significa uma concentração geográfica de firmas setorialmente especializadas, com tecido institucional associado. Consultar, por exemplo, Schmitz (1995)

3 Como assinala, entre outros, Foray (1991, p. 404):

"As formas de cooperação tecnológica, tanto intra quanto entre firmas, constituem o princípio básico de organização e funcionamento das firmas inovativas". 
regiões que exibem com destaque o que Storper (1995) designa como "interdependências não transacionadas" (untraded interdependencies), incluindo convenções, mercados de trabalho e instituições públicas, entre outros aspectos. Essas interdependências representam "ativos para a produção regionalmente específicos, materiais e não materiais" (Storper, 1995, p. 192). Realmente, a perspectiva de análise estribada na idéia de região de aprendizagem

salienta que o sucesso econômico regional é fortemente baseado em recursos definidos territorialmente, derivados de atributos de conhecimento e cognitivos 'unicos', freqüentemente tácitos, e ressalta a importância da proximidade espacial nos processos de aprendizagem coletiva. Ênfase considerável é colocada no papel central das estruturas institucionais regionais, que permitem às regiões (e às firmas no seu interior) se ajustar às mudanças no mercado, antecipando-se e moldando-se. Inovação e criação de conhecimento são vistas como processos interativos plasmados por um variado repertório de rotinas institucionais e convencões sociais. Isso envolve não simplesmente vinculos colaborativos entre empresas, mas também envolvendo firmas, Estado (local) e instituições da sociedade civil, o que chama a atenção para a permeabilidade dos limites entre economia, Estado e sociedade civil na criação da vantagem competitiva regional (Hudson, 1999, p. 64).
A aprendizagem de que se trata nas regiões de aprendizagem confunde-se com a própria dinâmica regional de inovação, quer dizer, com o

processo de geração, difusão e exploração de conbecimento em um dado território, tendo em vista o fomento do desenvolvimento regional (Landabaso, Oughton e Morgan, 1999, p. 471).

Como acentuam Lundvall e Borrás (1997), a economia de aprendizagem implica muito mais do que acesso às informações: o aspecto central é inovar na construção de competências e no plano do aperfeiçoamento e ampliação das habilidades. Daí que regiões de aprendizagem são, antes de tudo, regiões de inovação, as características das quais - extraídas, frise-se, da observação de experiências bem-sucedidas em termos de dinâmica inovativa e de posicionamento competitivo diante dos desafios que marcam o período atual, experiências estas observadas sobretudo em países localizados nas zonas centrais do capitalismo mundial - podem ser sintetizadas como segue:

Um cluster regional inovativo tende a abrigar firmas com (...) acesso a outras firmas, na condição de clientes, fornecedores ou parceiras, talvez em meio a redes formais ou informais; centros de conhecimento como universidades, institutos de pesquisas, or- 
ganizações de pesquisa contratada e agências de transferência de tecnologia importantes para os setores em questão; e uma estrutura de governança com associações privadas de negócios, câmaras de comércio, agências públicas de desenvolvimento econômico e de treinamento e promoção e departamentos governamentais. Quando ocorre desses elementos estarem disponiveis numa região, e, o que é crucial, de as observadas organizações mostrarem-se associativas (...), querendo isso indicar a existência de intercâmbio sistêmico, ou seja, regular, de mão dupla, sobre assuntos de importância para a inovação e a competitividade das firmas, pode-se considerar que se trata de um sistema regional de aprendizagem. Quando a tudo isso se adiciona a capacidade financeira, pela existência da infra-estrutura financeira necessária para que as firmas obtenham o que precisam para ousarem investir no sentido de gerar inovações endogenamente, pode-se falar de um sistema regional de inovação (Cooke, Uranga e Etxebarria, 1997, p. 484 - em itálico no original).

Deve-se assinalar ainda que, nas regiões de aprendizagem, o setor público está longe de se mostrar inerte. Florida (1995) chama a atenção, por exemplo, para o significado das infra-estruturas - de amparo à produção, envolvendo inclusive encorajamento à criação e operação de redes, de formação/aperfeiçoamento de recursos humanos e também de comunicações -, cuja materialização requer a irrevogável iniciativa do Estado. Todavia, o papel que cabe ao setor público transcende a esfera da infra-estrutura, pois sua atuação como catalisador das interações entre os integrantes do sistema de inovação é normalmente de grande importância. Com efeito, as possibilidades dos sistemas socioprodutivos territorializados não dependem somente de infra-estrutura para atividades de pesquisa e desenvolvimento. Talvez acima de qualquer coisa, os elementos-chave são "a qualidade dos vínculos e a presenca de sinergia local (...)" (Morgan, 1997, p. 496). Aliás, as recomendações dirigidas à promoção do desenvolvimento local-regional com base, prioritariamente, na criação e no fortalecimento de redes mostram-se permeadas desse tipo de entendimento.

Para finalizar esta subseção, convém indicar que a abordagem em termos de regiões de aprendizagem não detém qualquer "prerrogativa analítica" sobre o tema da inovação e do papel das relações de proximidade nos processos de aprendizagem e difusão do conhecimento. $\mathrm{O}$ tripé conhecimento-aprendizagem-inovação tem presença, de fato, na reflexão sobre desenvolvimento local-regional, quer na perspectiva dos distritos industriais italianos, explorada por autores como Beccatini 
(1992) e Garofoli (1992), quer na dos sistemas industriais localizados, associada a pesquisadores franceses como Courlet e Pecqueur (1992), ou ainda na dos distritos industriais em que se sublinha a importância da eficiência coletiva, ultrapassando, conforme reivindicado, a herança marshalliana (por exemplo, Schmitz, 1995 e 1998), além de marcar contribuições "californianas", em meio às quais se destacam as de Storper (por exemplo, Storper, 1995).

Todavia, em nenhum desses enfoques se dá tanta ênfase à importância da capacidade de aprender, de um lado, e à importância da inovação, de outro lado ambas aparecendo estreita e irremediavelmente vinculadas -, quanto se observa nas análises em termos de região de aprendizagem. Tendo em vista que tal abordagem figura, como uma espécie de derivação, em linha argumentativa que atribui ao conhecimento e à aprendizagem, pela ordem, a condição de recurso mais estratégico e o processo de maior importância no capitalismo moderno (Morgan, 1997), esse grande realce não deve surpreender. A rigor, os avanços na abordagem das regiöes de aprendizagem podem estar indicando que

está a caminho uma convergência teórica potencialmente significativa entre os (...) campos, até agora distintos, dos estudos da inovação e da geografia econômica (Morgan, 1997, p. 491).

\section{4_A idéia de "região de aprendizagem" como "chave de leitura" sobre experiências concretas}

Conforme já assinalado, os traços das regiōes de aprendizagem anteriormente expostos figuram em literatura que descreve e analisa realidades socioprodutivas específicas: aquelas situadas em países mais ricos. É, de fato, a partir de experiências européias (como em Hudson, 1999; Morgan, 1997, por exemplo) e estadunidenses (Storper, 1995 e Florida, 1995, entre outros), que se relaciona a expressão região de aprendizagem à presença de recursos territoriais tidos como "únicos" e dificilmente observáveis alhures do mesmo jeito; à atuação de instituições públicas e privadas - de pesquisa, produção/transmissão de conhecimentos e de outras naturezas -, que, compondo estruturas de governança, favorecem respostas locais realmente sintonizadas com as mudanças nos mercados; ao intercâmbio sistêmico necessário à inovação, importante para a competitividade, representando tessitura "espessa" de vínculos colaborativos formais ou não; e à capacidade financeira capaz de estimular e sustentar iniciativas de geração endógena de inovações. Quer dizer, essas características conformam perfis de casos geralmente bem-sucedidos em matéria de concentração espacial de atividades produtivas e inovadoras. 
Ora, estudos sobre diferentes experiências em países externos ao centro do capitalismo mundial mostram quão diferente é a situação das correspondentes aglomerações produtivas comparativamente aos atributos identificados nos países ricos. Nadvi e Schmitz (1994), em pesquisa sobre clusters de vários países de América Latina, África e Ásia, detectam forte heterogeneidade tanto entre as experiências quanto no interior delas (o que remete, de passagem, à questão das hierarquias internas aos tecidos produtivos e institucionais), mostrando-se sugestivo que várias tenham merecido dos autores a designação de aglomerações "pouco pronunciadas", tendo em vista o nível de precariedade percebido.

Assim, se o "compartilhamento de conhecimentos sobre desenvolvimento de produto, sobre mercados de trabalho e sobre o nível de confiança de outros produtores, de comerciantes e de fornecedores (...) mostrou-se aspecto presente em grande parte das aglomerações setoriais" (Nadvi e Schmitz, 1994, p. 28), somente em algumas poucas realidades, entre as estudadas pelos mencionados pesquisadores, tal característica "resultou em inovações e desenvolvimento de produto significativos" (Nadvi e Schmitz, 1994, p. 42), a maior incidência de avanços dizendo tão-somente respeito às "formas incrementais de desenvolvimento tecnológico e de processo" (Nadvi e Schmitz, 1994, p. 42). Ou seja, tais aglomerados exibem, por exemplo, dinâmicas ao estilo do learning-by-interacting, mas a aprendizagem tende a não gerar as conseqüências notadas nos casos de regiões de aprendizagem captados pela literatura sobre as zonas centrais do capitalismo mundial.

Alguns autores argumentam que as dificuldades registradas nessas realidades distantes do centro do capitalismo derivam da própria condição periférica dos respectivos contextos. Problematizando os processos de criação, transmissão e absorção das externalidades de conhecimento em "espaços periféricos", Santos, Crocco e Jayme Jr. (2005) discutem as condições que geralmente lhes são subjacentes. Essas condições envolvem desde as elevadas volatilidade e instabilidade dos ambientes externos até os problemáticos aspectos dos entornos dos lugares de geração de conhecimento, passando pelo direcionamento para fins eminentemente produtivos - em vez de inovativos - da capacitação tecnológica protagonizada e pela estreiteza da demanda, o último aspecto mostra-se agravado pela escassa capacidade de absorção do conhecimento, cujas formas de divulgação, ainda por cima, tendem a se mostrar insuficientes. Em síntese, as referidas con- 
dições dizem respeito a problemas situados no plano da precariedade dos sistemas de inovação.

A postulação desses autores é que, na periferia do capitalismo mundial,

o potencial de aprendizagem, o escopo para upgrading tecnológico e os spillovers de conbecimento são consideravelmente limitados. Em outras palavras, a construção de capacidades de países periféricos com base na transferência de conbecimento produz um ambiente que não facilita a geração disseminada das externalidades de conhecimento (...) (Santos, Crocco e Jayme Jr., 2005, p. 14).

Desse modo, haja vista, entre outras coisas, a inferioridade relativa das capacitações para inovação e as dificuldades e desvantagens dos ambientes organizacionais e institucionais, os processos de aprendizagem nessas aglomerações costumam apresentar menor intensidade e menores níveis de absorção do conhecimento, comparativamente falando, com inevitáveis reflexos no dinamismo inovador.

Portanto, focalizar realidades "periféricas" na perspectiva de encontrar as mesmas condições que sustentam o desempenho das regiões de aprendizagem localizadas nas zonas centrais do capitalismo tende a configurar procedimento fadado ao insucesso já de partida. A fragilidade das relações que permeiam o espaço social de- corrente do próprio “desenvolvimento periférico", marcadamente desigual, deve dissipar quaisquer ilusões a respeito disso: tal

aspecto tem influência sobre o nivel local, pois, da mesma forma que na esfera nacional, ele dificulta o surgimento de interacoões entre os agentes de aglomerações industriais de forma a torná-las inovativas (Santos, Crocco e Lemos, 2002, p. 175).

Conforme anunciado no título deste artigo, o que se pretende no texto é explorar a idéia de região de aprendizagem como temática e ângulo de observação. Tendo em vista as considerações acima, o fato de tal idéia - segundo aparece na literatura internacional - ter sido construída a partir da observação de experiências no capitalismo central há de representar, em abordagens de realidades periféricas, uma exploração não mais do que na forma de "chave de leitura". Assumindo que a problemática das regiões de aprendizagem é útil à reflexão sobre situações concretas, dizer "chave de leitura" significa referir à orientação do olhar, em direção a aspectos considerados de relevo na realidade perscrutada, por alguns termos importantes dessa problemática. Mas isso não deve representar, sublinhe-se, tentativa de comparação entre as situações investigadas e o "modelo" de região de aprendizagem apresentado na literatura internacional. 
Nos dois estudos que formam a seqüência do artigo, sobre as aglomerações têxtil-vestuarista e ceramista do Médio Vale do Itajaí e do Sul de Santa Catarina, os termos da problemática das regiōes de aprendizagem privilegiados dizem respeito, fundamentalmente, à institucionalização da aprendizagem e aos vínculos interfirmas, centrais na ótica da abordagem em foco. Todavia, em nenhum dos casos, pretende-se conferir a existência dos mesmos tipos de elemento geralmente detectados em ambientes do capitalismo central. Isso representaria procedimento vão. As próprias características estruturais da realidade periférica tendem a representar limites às possibilidades das aglomerações produtivas em tais contextos. De um modo geral, essas características representam barreiras à

ocorrência de um processo de 'learning inovativo' dentro de tais aglomerações, resultando apenas em um processo de 'learning produtivo' (Santos, Crocco e Lemos, 2002, p. 175 - itálico no original).

\section{Produção têxtil-vestuarista no Médio Vale do Itajaí}

A história da produção têxtil-vestuarista no Médio Vale do Itajaí confunde-se com a da colonização dessa área, no século XIX, por contingentes de origem sobre- tudo germânica. Entre os principais marcos dessa trajetória, figura a criação, em 1880, da Cia. Hering, em Blumenau, principal cidade da região (Hering, 1987). Desde então, também beneficiada por diversas circunstâncias favoráveis, a produção têxtil-vestuarista regional conquistou espaço no mercado brasileiro e, pelo menos no que concerne às principais empresas, penetrou e galgou posições em mercados externos. De meados do século XX em diante, a evolução da cadeia produtiva resultou em expansão do segmento vestuarista, com proliferação de empresas de menor porte que, sem se restringirem à prestação de serviços de beneficiamento para outras empresas, oferecem um grande e variado leque de produtos.

A senda percorrida redundou na formação de um verdadeiro cluster têxtil-vestuarista, em que se produzem fios, tecidos, roupas de cama-mesa-banho e diversos artigos para vestuário. De fato, o Médio Vale do Itajaí concentra atributos como mercado de trabalho dotado de trabalhadores com habilidades especializadas, fornecedores de máquinas e equipamentos (até com representantes de fabricantes estrangeiros), serviços diversos e tecido institucional composto por organismos tanto de criação e difusão de conhecimento como por entidades de coordenação e representação, importan- 
$\cdots \ldots \ldots \ldots$

4 Uma abordagem mais ampla sobre o cluster têxtil-vestuarista do Médio

Vale do Itajaí, inclusive com uma discussão sobre a problemática do desenvolvimento regional, pode ser encontrada em Lins (2000a).

5 Entrevistas realizadas pelo autor no âmbito de pesquisa mais abrangente. tes na estrutura de governança local. Somadas às possibilidades de divisão do trabalho na produção (principalmente pelas condições para subcontratação e terceirização) e de acesso a serviços e conhecimentos especializados (impregnados em diversas atividades conexas), essas qualidades representam notável estoque de economias externas e de aglomeração. ${ }^{4}$

\section{1_ Institucionalização da aprendizagem}

Importante aspecto desse aglomerado é o fato de o Médio Vale do Itajaí ser depositário de conhecimento técnico acumulado por gerações de trabalhadores ao longo de mais de um século de vivência têxtil-vestuarista. Pode-se aludir, com efeito, à presença de uma verdadeira "cultura" setorial na área, profundamente enraizada e que significa um valioso recurso intangível. Daí não surpreender que informações obtidas por meio de entrevistas $^{5}$ - em 22 empresas e em instituições locais - revelem grande apreço de vários tipos de agente pelas condições relacionadas ao conhecimento impregnado no sistema e às habilidades dos trabalhadores. Note-se que é principalmente em relação às características da mão-de-obra que a herança sociocultural da região, de matriz essencialmente germânica, aparece com realce em alguns pontos de vista captados. Isso é tanto mais merecedor de destaque haja vista as consideráveis mudanças locais - principalmente na configuração do mercado de trabalho - associadas às migrações registradas no Médio Vale do Itajaí nas últimas décadas, com origem em outras regiões de Santa Catarina e em outros Estados.

O enraizamento do conhecimento técnico auxilia a entender o dinamismo historicamente ostentado pela região no tocante à multiplicação de estabelecimentos produtivos, como ocorreu nos anos 70 e 80 . Tudo leva a crer que numerosas unidades foram criadas por ex-funcionários de empresas, maiores e mais antigas, os quais, desligados por demissão ou aposentadoria, resolveram utilizar em proveito próprio o know-how acumulado e aperfeiçoado durante anos de experiência têxtil-vestuarista. Tal processo contribuiu para a proliferação de empresas de tamanhos variados, mas principalmente as micros e de pequeno porte, em cadência geralmente sintonizada com o ritmo dos ajustes implementados em escala de sistema local.

As instituições da área têm tido um papel não negligenciável na difusão de conhecimento e na aprendizagem. Os instrumentos para educação profissional (com diferentes tipos de curso) e a in- 
fra-estrutura tecnológica (sistemas CAD acessíveis às empresas, por exemplo), entre outros aspectos, fazem do Serviço Nacional de Aprendizagem Industrial (Senai) um organismo sempre referido pelos agentes do cluster. Os Centros de Educação e Tecnologia (CETs) dessa instituição, observados em Blumenau e em Brusque (outra importante cidade da área, considerada "berço da fiação catarinense"), desenvolvem amplo conjunto de atividades, devendo-se assinalar que o CET de Blumenau viu surgir (em 1999) um Centro de Tecnologia do Vestuário criado para atuar em ensino tecnológico, assistência técnica e tecnológica, difusão de informações tecnológicas e pesquisa aplicada; em 2002, ocorreu a instalação de um Centro de Tecnologia Têxtil (Rocca, 2003). Os laboratórios locais também merecem destaque: o Centro de Pesquisas e Desenvolvimento de Estudos Têxteis (Cepetex) e a Fundação Blumenauense de Estudos Têxteis (FBET), situados em Blumenau, realizam testes de resistência, alongamento e imperfeições em fios e fibras; em Brusque observam-se os serviços do Laboratório de Ensaios Físicos e Químicos Têxteis (LEFQT). Igualmente merecedor de referência é o papel desempenhado pela Universidade Regional de Blumenau (FURB).
A região também abriga instituições com atuação pautada na representação/auto-ajuda e na coordenação dos agentes. Cabe mencionar, principalmente, a Associação Comercial e Industrial de Blumenau (ACIB) e o Sindicato das Indústrias de Fiação, Tecelagem e do Vestuário de Blumenau (Sintex), espaços de articulação por excelência do empresariado têxtil-vestuarista regional. Segundo Tomio (1995), ambos têm sido controlados pela elite empresarial local, porém suas características não são idênticas. $\mathrm{O}$ Sintex parece ter privilegiado, historicamente, os interesses do grande empresariado: a tendência à fixação de taxas de contribuição elevadas e à não-adoção de estímulos de caráter seletivo, direcionados para diferentes tamanhos de empresa, estaria a denotar essa orientação. A ACIB parece ter norteado as suas atividades por objetivos de caráter mais includente, estabelecendo uma articulação mais ampla do empresariado regional: é exemplo a tentativa de ampliar o envolvimento de empresas menores por meio da oferta de serviços, da programação de cursos de especialização e de eventos e do estímulo e apoio à participação dos fabricantes em feiras no Brasil e no exterior. Não há equívoco em afirmar que as posições de ambas as entidades figuram 
entre as de maior relevância na estrutura de governança local.

Com efeito, a atuação das instituições de representação/auto-ajuda e coordenação parece ter sido decisiva em diferentes iniciativas testemunhadas na área. Uma delas disse respeito à criação de uma importante feira em Blumenau, a Expotêxtil (tornada Textfair posteriormente), evento que, realizado periodicamente desde meados dos anos 90, estaria a representar oportunidades de negócios e ocasião para tornar mais fluidas as inter-relações no cluster. Sua maior importância provavelmente reside no que a participação nas correspondentes atividades significa para as firmas de menor porte, haja vista que, em geral, as micros e pequenas empresas padecem de grandes carências estruturais e dificilmente conseguem assegurar por conta própria as condições capazes de propiciar uma maior vitalidade para seus negócios.

Em Brusque, é importante indicar a confluência de interesses empresariais envolvendo a indústria têxtil-vestuarista e o setor turístico, encorajada pela localização da cidade em região onde ocorrem as principais "festas de outubro" em Santa Catarina (cujo maior destaque é a Oktoberfest de Blumenau). Os festejos representam não só homenagem à cultura dos imigrantes europeus que se insta- laram na região e modelaram a socioeconomia dessa, mas também - talvez sobretudo - oportunidades para a realização de negócios. Contribuiu para o progresso dessa referida articulação indústria-turismo a proximidade de um litoral pontilhado por núcleos turísticos, o mais divulgado e melhor consolidado dos quais é o Balneário Camboriu, cujo prestígio até internacional se manifesta na condição de ponto de convergência de grandes fluxos de visitantes. A programação (anual) da Feira Industrial de Brusque nos meses de janeiro e fevereiro, auge da movimentação turística em Santa Catarina, pode ser considerada uma boa ilustração desse "entrelaçamento" envolvendo a indústria têxtil-vestuarista e o setor de turismo.

Outro exemplo de atuação institucional conseqüente foi a que resultou em campanha iniciada em 1997, no município de Brusque, visando levantar recursos para financiar a divulgação da cidade em nível nacional e a realização de cursos de profissionalização para funcionários (de diferentes empresas) que se relacionam diretamente com os clientes. Essa iniciativa floresceu no seio da Comissão Executiva para o Desenvolvimento de Brusque, integrada por organismos municipais como a Secretaria de Desenvolvimento Econômico e Turismo da pre- 
feitura, a Associação Comercial e Industrial, a Câmara de Dirigentes Lojistas e a Associação de Micros e Pequenas Empresas. Cabe mencionar ainda a iniciativa conhecida como "Rodada de Negócios", realizada desde 1997 em duas edições anuais, implicando a apresentação sazonal de coleções de artigos de vestuário. Organizado pela Associação de Médias e Pequenas Empresas de Brusque, esse evento tem atraído numerosos compradores potenciais para os produtos da área, em trajetória de contínuo fortalecimento (Henschel, 2002).

A conclusão que se impõe é que as atividades do complexo têxtil-vestuarista instaladas no Médio Vale do Itajaí desenvolvem-se amparadas por uma base institucional de "espessura" não negligenciável. Há instituições cuja atuação é mais voltada às questões do conhecimento e à difusão desse, representando esteio dos processos de aprendizagem, e outras que despontam uma estrutura de governança com potencial até para fomentar a cooperação interfirma.

\subsection{Vínculos interfirmas}

Várias firmas da região entendem que o ambiente socioprodutivo no qual se inserem apresenta cooperação interempresarial. Todavia, esse diagnóstico geralmente não reflete, historicamente, muito mais do que relações de boa vizinhança abrangendo empréstimos de matérias-primas e insumos e também algum auxílio em certas ocasiões (como durante as enchentes que pontuam a trajetória do Vale do Itajaî. Cooperação propriamente dita, marcada por efetivos vínculos verticais (ao longo da cadeia produtiva) e horizontais (entre agentes em posição semelhante na estrutura da indústria) em nível local, parece ocorrência rara, algo coerente com a tradição local de escassas relações interfirmas.

Com respeito às relações verticais, deve-se assinalar que, na produção têxtilvestuarista, caracterizada por feixe de atividades de tecnologia madura, o conhecimento é em grande parte codificado, com inovações transmitidas principalmente por meio de bens de capital e insumos. Ora, maquinário e fibras têxteis são provenientes de fora da região, o que significa, para grande número de fabricantes, ínfimas relações locais de cooperação com fornecedores. De outra parte, afora o desempenho comercial de uma certa quantidade de produtores de malhas em rolo, fios e tecidos que fornecem para empresas regionais (geralmente micros e pequenas), o escoamento da produção têxtil-vestuarista do Médio Vale do Itajaí ocorre em diferentes mercados, no Brasil e no exterior, o que representa vínculos escassos com clientes no plano regional. Quanto às relações hori- 
zontais, há reuniões freqüentes entre os empresários mais tradicionais e manifestações de simpatia por medidas aptas a representar ganhos coletivos, mas, ao que tudo parece indicar, o espírito prevalecente na área, em que se misturam individualismo, rivalidade e desconfiança, tem-se afigurado uma difícil barreira às interações efetivas, pelo menos até recentemente.

A Tabela 1 informa sobre o comportamento das interações de um grupo de empresas locais, de médio e grande portes, na segunda metade dos anos 90, diferenciando os vínculos com interlocu- tores de dentro e de fora do aglomerado. Chamam a atenção o crescimento das relações com clientes e fornecedores de bens de capital situados fora da região, a intensificação do diálogo com fornecedores de insumos tanto internos como externos à área, a tendência de estabilidade nos vínculos com centros tecnológicos, universidades e instituições de coordenação e representação/auto-ajuda do interior e do exterior do aglomerado e, talvez, sobretudo, o encolhimento na interlocução com concorrentes, em particular os do plano interno.

Tabela 1_ Médio Vale do Itajaí: comportamento das interações de grandes e médias empresas têxtil-vestuaristas na segunda metade dos anos 90

\begin{tabular}{|c|c|c|c|c|c|c|c|c|c|}
\hline \multicolumn{2}{|c|}{$\begin{array}{c}\text { Participação das empresas } \\
\text { (\%) }\end{array}$} & \multirow{2}{*}{$\begin{array}{c}\text { Clientes } \\
0\end{array}$} & \multirow{2}{*}{\begin{tabular}{|c|} 
Concorrentes \\
30,8 \\
\end{tabular}} & \multirow{2}{*}{\begin{tabular}{|c|}
$\begin{array}{c}\text { Fornecedores } \\
\text { de insumos }\end{array}$ \\
0 \\
\end{tabular}} & \multirow{2}{*}{$\begin{array}{c}\text { Fornecedoes } \\
\text { de máquinas e } \\
\text { equipamentos }\end{array}$} & \multirow{2}{*}{$\begin{array}{c}\begin{array}{c}\text { Centros } \\
\text { tecnológicos }\end{array} \\
6,2 \\
\end{array}$} & \multirow{2}{*}{\begin{tabular}{|c|} 
Universidades \\
7,7 \\
\end{tabular}} & \multirow{2}{*}{$\begin{array}{c}\text { Sindicatos e } \\
\text { associações }\end{array}$} & \multirow{2}{*}{$\begin{array}{c}\begin{array}{c}\text { Órgãos } \\
\text { públicos }\end{array} \\
21,4\end{array}$} \\
\hline \multirow{5}{*}{$\begin{array}{l}\text { Relações no } \\
\text { aglomerado }\end{array}$} & Forte dimin. & & & & & & & & \\
\hline & Diminuição & 6,2 & 15,4 & 0 & 0 & 0 & 7,7 & 0 & 0 \\
\hline & Estável & 31,3 & 38,5 & 20,0 & 50,0 & 56,3 & 46,1 & 56,3 & 42,9 \\
\hline & Aumento & 50,0 & 7,7 & 60,0 & 41,7 & 31,2 & 38,5 & 18,7 & 28,6 \\
\hline & Forte aum. & 12,5 & 7,7 & 20,0 & 0 & 6,3 & 0 & 12,5 & 7,1 \\
\hline \multirow{5}{*}{$\begin{array}{c}\text { Relações } \\
\text { extra- } \\
\text { aglomerado }\end{array}$} & Forte dimin. & 0 & 15,4 & 0 & 0 & 18,2 & 40,0 & 37,5 & 20,0 \\
\hline & Diminuição & 0 & 23,1 & 0 & 0 & 0 & 0 & 0 & 10,0 \\
\hline & Estável & 0 & 53,8 & 31,3 & 25,0 & 36,4 & 40,0 & 37,5 & 30,0 \\
\hline & Aumento & 73,7 & 7,7 & 43,7 & 56,3 & 36,3 & 20,0 & 12,5 & 40,0 \\
\hline & Forte aum. & 26,3 & 0 & $25,0$. & $18,7$. & $9,1$. & 0 & 12,5 & 0 \\
\hline
\end{tabular}

Fonte: Campos, Cário e Nicolau (2000).

Obs.: Os dados referem-se a uma amostra de 19 empresas. 
De todo modo, há indicações de que alguma ação conjunta teve lugar entre grupos de empresários. As de maior destaque dizem respeito às iniciativas brusquenses envolvendo a instalação de centros comerciais para estimular o "turismo de compras", com reflexos nas vendas e na produção. Esse tipo de iniciativa, vale assinalar, foi observado também em outras áreas produtoras de artigos têxteis e de vestuário no Estado, como Jaraguá do Sul, no Nordeste catarinense, e Criciúma, ao Sul (Lins, 2000b). Em Brusque, as experiências de cooperação incluíram igualmente acordos para a uniformização de preços, quer entre empresas de tecelagem, quer entre empresas que prestam serviços de tinturaria, assim como tentativas de associação entre fabricantes de felpudos para debater problemas de interesse do segmento.

Entretanto, os movimentos com esse teor têm sido episódicos e, devido geralmente a discordâncias ou à quebra de confiança (como ocorreu nos exemplos mencionados), têm apresentado duração efêmera. Em quase todas as referências captadas nas entrevistas junto às empresas, viu-se que a tônica, com respeito ao assunto, é a frustração das expectativas. Assim, não surpreende ser forte, entre os atores locais, a convicção de que as condutas individualistas - além de tudo marcadas pela rivalidade - são as que efetivamente predominam no aglomerado.

De qualquer maneira, após a crise que assolou o Médio Vale do Itajaí na segunda metade dos anos 90 - associada à abertura comercial do Brasil e à política de câmbio do Plano Real, que resultaram em enxurrada de importações e dificuldades para exportar -, foram esboçados alguns interessantes movimentos baseados em ação coletiva. Meyer-Stamer (1999) descreve a iniciativa, sob uma liderança regional, idealizada para representar o início de um processo de mudança, a partir de uma viagem de fabricantes locais à Itália - objetivando adquirir conhecimento sobre a bestpractice nas interações e na promoção do ambiente mesoeconômico para as atividades em questão - que deveria estimular uma melhoria na circulação de informações entre as firmas, uma maior cooperação do setor com a universidade local, a promoção da formação profissional e o estímulo à criação de marca regional.

Escassez de espírito cooperativo prevalece também nos vínculos de subcontratação. Conforme assinalado, entre as características desse cluster, figura a presença de numerosas unidades de trabalho (formais ou não, inclusive em 
domicílio), aptas a canalizar a transferência de atividades das empresas que externalizam etapas de seus processos de fabricação. A subcontratação representa muito pouco em termos de cooperação devido à natureza dessa prática na área, de uma forma geral: a transferência de atividades é motivada pelo interesse das empresas subcontratantes em reduzir custos (salários e encargos sociais) e ampliar a flexibilidade nas respostas às oscilações do mercado. Desse modo, trata-se, geralmente, de subcontratação "concorrencial" ou de "capacidade" (e não de "especialização") e "conjuntural" (em vez de "estrutural").

Esse tipo de relação, ampliado durante a reorganização produtiva que marcou os anos 90, é permeado de incertezas e tende a apresentar caráter tenso, fruto das pressões dos subcontratantes com respeito a preços e prazos. Esse perfil de subcontratação predominou na crise das indústrias têxteis e vestuaristas, durante parte da década passada, por conta do poder de barganha outorgado aos subcontratantes pelas próprias dificuldades do período, as quais se traduziram, entre outras coisas, em volumosas e inquietantes demissões. Largamente precários, tais vínculos apresentam-se, portanto, escassamente cooperativos.
Assinale-se que o aprofundamento da subcontratação intensificou no Médio Vale do Itajaí a tendência à criação de cooperativas de trabalho, já observada com vigor em outros Estados do Brasil. $\mathrm{Na}$ região, e dizendo respeito às indústrias têxteis e vestuaristas, trata-se de cooperativas normalmente formadas de ex-funcionários (em geral ex-costureiras) por estímulo das próprias empresas que os desligaram, as quais passam a transferir às primeiras várias atividades de seus processos produtivos. Para os subcontratantes, isso representa, além de menores custos, também vantagens logísticas, pois permite o direcionamento de grandes volumes (na maioria peças a ser costuradas) para poucos destinos. Da mesma forma, significa benefícios relacionados ao uso de trabalhadores confiáveis (as costureiras implicadas são geralmente conhecidas das empresas) e hábeis, capazes de atender aos requisitos de qualidade e cumprimento dos prazos.

Outro aspecto é que o aumento da subcontratação, acelerador da substituição da mão-de-obra interna inclusive pela maior velocidade conferida ao processo de demissões, tendeu a exacerbar o caráter precário das relações de trabalho nos anos 90. Esse foi o caso também nas cooperativas de trabalho, pois a realidade 
dessas estruturas envolve ritmos de produção muito acelerados e uma grande atenção às exigências de qualidade (Lins, 2003). Não admira, por conseguinte, que os anos 90 tenham assistido ao recrudescimento do combate à terceirização produtiva no âmbito do Sindicato dos Trabalhadores nas Indústrias de Fiação e Tecelagem de Blumenau. As razões eram claras:

direitos como Fundo de Garantia, $13^{\circ} \mathrm{sa}$ lário, férias, licença-maternidade, aposentadoria, etc. não existem no trabalho terceirizado (Terceirização..., 1997, p. 1).

Todavia, as grandes empresas parecem ter percebido que suas possibilidades frente às pressões da concorrência dependiam de uma maior agregação de valor aos produtos, em sintonia com as tendências internacionais. A produção simultânea de grandes volumes de artigos padronizados, com marcas reconhecidas, e de pequenas quantidades de artigos de moda, com elevado grau de diferenciação e dirigidos para nichos de mercado específicos, passou a ser percebida como estratégica. ${ }^{6}$ Ora, a segunda modalidade representa campo de atuação privilegiado para estruturas menores e ágeis, capazes de reagir de modo flexível às variações na demanda, quer dizer, para micros e pequenas empresas com padrão de qualidade e produtividade que franqueie o acesso aos espaços de subcontratação das companhias maiores. Segundo um diretor de uma grande e tradicional empresa de Blumenau, 7 essa "necessidade" das firmas maiores poderia representar uma valiosa oportunidade para o fortalecimento das micros e pequenas empresas, pois as carências estruturais desses segmentos haveriam de ensejar processos de capacitação - implicando aprendizagem - promovidos e sustentados pelas primeiras. Assim, vínculos mais ricos e densos poderiam ser construídos, com benefícios multifacetados e multilaterais.

Entretanto, a realidade dos laços estabelecidos no turbilhão de subcontratações que marcou as indústrias têxteis e vestuaristas de Santa Catarina - no bojo do qual uma empresa como a Hering chegou a terceirizar a maior parte das suas atividades de costura, tanto no Médio Vale do Itajaí como em municípios de várias regiões do Estado - sugere que a aprendizagem de que se trata, nos vínculos estabelecidos entre as grandes empresas e as micros e pequenas unidades de produção, tem sido muito mais voltada à "inoculação" do sentido fabril em estruturas geralmente familiares e não (ou pouco) profissionalizadas. O que muitas microempresas aprenderam nesses esquemas de subcontratação, basicamente, foi montar artigos de vestuário de acordo

\footnotetext{
6 Um caminho largamente percorrido, num certo período, por uma empresa como a Hering, de acordo com reportagem de Martinez (1998).

7 Manifestada na condição de dirigente da Associação Comercial e Industrial de Blumenau durante evento científico realizado em setembro de 1997 nessa cidade.
} 
com os parâmetros de qualidade e produtividade adequados aos interesses das grandes empresas. Ou seja, está-se diante de um learning produtivo, sem vestígios, praticamente, de um learning inovativo, para usar as expressões de Santos, Crocco e Lemos (2002).

\section{Produção cerâmica no Sul catarinense}

Principal espaço de produção de pisos e azulejos em Santa Catarina, tornado uma referência nacional nessa atividade, o "Sul catarinense ceramista" desdobrase sobre um conjunto de municípios que tem Criciúma como cidade mais importante e que apresenta relação histórica com atividades de mineração e beneficiamento de carvão, durante décadas o recurso econômico regional básico. Tratase, no Estado, da área onde é mais forte a influência da imigração italiana para o Sul do Brasil no século XIX. No início com estrutura produtiva tipicamente colonial, assentada na agricultura e em atividades conexas, a economia da região atravessou grande parte do século XX exibindo o referido peso do setor carbonífero (é a mais importante área carbonífera do País, visto ser a única que possui minério para uso tanto energético quanto metalúrgico), apresentando posteriormente di- versificação no curso da qual a cerâmica de revestimento representou o setor de maior realce.

A origem dessa indústria vinculase principalmente às iniciativas de alguns descendentes de imigrantes italianos que, estimulados pela disponibilidade de matéria-prima, realizaram durante décadas uma produção de baixo dinamismo e reduzida sofisticação, em algumas poucas unidades produtivas. A impulsão só veio a partir dos anos 60 , e sobretudo desde os 70 , com o aquecimento do setor de construção civil alimentado pela política habitacional do País. $\mathrm{Na}$ esteira da dinamização do mercado, as empresas já instaladas se expandiram ou se reestruturaram e novas empresas foram criadas, em processo que, não obstante os períodos de dificuldades, ganhou vulto e resultou na estrutura observada na atualidade. Assim, pode-se falar, hoje, no funcionamento de um verdadeiro cluster cerâmico no Sul de Santa Catarina.

\section{1_ Institucionalização da aprendizagem}

$\mathrm{O}$ aglomerado ceramista Sul-catarinense é integrado por vários fabricantes de pisos e azulejos, em Criciúma e arredores, em torno dos quais gravitam fornecedores de insumos e matérias-primas - a cujo grupo pertencem algumas filiais de empresas multinacionais que disponibili- 
zam fritas e produtos químicos empregados na produção de esmalte cerâmico - e também fabricantes de bens de capital para a produção cerâmica e de embalagens utilizadas pelos ceramistas. O conjunto abriga ainda instituições como o Sindicato dos Ceramistas (o Sindiceram), estruturas de ensino superior e técnico-profissional e, desde 1995, o Centro de Tecnologia em Cerâmica (CTC), tornado Centro Tecnológico de Cerâmica e Materiais (CTCmat) no início da década em curso. ${ }^{8}$

A convivência da área com o universo da produção cerâmica durante muitos anos e sobretudo a sucessão de eventos que deram ao cluster as suas atuais feições (criação de instituições, expansão dos sistemas de formação superior e técnico-profissional, chegada de novas empresas com presença distribuída na cadeia), nutriram os processos de aprendizagem, engendrando considerável acúmulo de conhecimento técnico e tecnológico em escala regional. Com efeito, na trajetória percorrida, adquiriu forma um razoável bolsão de mão-de-obra capaz de atuar em diferentes tipos de atividade relacionada ao setor, em boa medida como resultado de treinamento dentro das próprias empresas, mas também por conta dos programas de formação técnica oferecidos por instituições locais.
As iniciativas referentes a esses programas merecem realce. A importância adquirida pela indústria cerâmica, em região que enfrentou momentos adversos por conta das oscilações e incertezas que caracterizaram a evolução do setor carbonífero, fortaleceu o entendimento local sobre a necessidade de solidificar as bases do referido tecido produtivo e institucional, no intuito do seu desenvolvimento. Assim, por exemplo, além dos esforços voltados à educação técnica, materializados há bastante tempo em escala de empresa e também fora do âmbito empresarial, o sistema regional de capacitação de recursos humanos passou a registrar nível de formação em Tecnólogo em Cerâmica e em Engenharia de Materiais na estrutura acadêmica da Universidade do Extremo Sul Catarinense (Unesc). Isso evoca um certo grau de engajamento comunitário (envolvendo empresas e instituições públicas e privadas) na promoção do setor.

Mas o principal marco do fortalecimento institucional do aglomerado refere-se à criação do agora denominado CTCmat. Trata-se, provavelmente, do maior exemplo de cooperação multilateral no âmbito do sistema local, tendo florescido como resultado da convergência de interesses e iniciativas que aglutinaram o Sindiceram, o Senai, a Universidade Fe-

\footnotetext{
Sobre a composição do cluster e a identificação dos seus agentes, consultar Campos, Nicolau e Cário (1999) e Cário e Enderle (2005).
} 
deral de Santa Catarina (por intermédio do Centro Tecnológico dessa instituição), a Federação das Indústrias do Estado de Santa Catarina e a Fundação de Ciência e Tecnologia do Estado, hoje denominada Fundação de Apoio à Pesquisa Científica e Tecnológica do Estado de Santa Catarina (Fapesc).

Pela sua natureza, esse centro poderá vir a despontar, no longo prazo, como um divisor de águas no percurso da aglomeração ceramista. Induz a pensar desse modo o papel que as instituições tecnológicas normalmente desempenham em sistemas produtivos locais. Quando bem equipadas e suficientemente enraizadas nos ambientes socioprodutivos, essas instituições captam e, na maneira como operam, geralmente refletem as necessidades locais, contribuindo para a criação e difusão de conhecimento e para os processos de aprendizagem locais. Por conseguinte, tendem a desempenhar um papel decisivo na promoção do desenvolvimento industrial e local-regional. Especialmente relevantes, amplamente falando, são as interações protagonizadas com agentes e instituições situados fora da circunvizinhança imediata, pelo que isso possibilita de atualização constante de procedimentos e de conhecimentos em geral, com repercussão na dinâmica dos processos de aprendizagem.
O CTCmat parece concentrar potencial para cumprir funções dessa natureza, no que toca à problemática das inter-relações. De fato, a instituição foi idealizada para atuar em educação profissional, informação tecnológica, assessoria técnica e tecnológica e pesquisa aplicada, ostentando infra-estrutura laboratorial e capacidade técnica que lhe tem permitido atender demandas originárias até de outras regiões e de outros Estados do Brasil. No entanto, em que pesem as potencialidades incrustadas e a proeminência já adquirida, a instituição não deixou de enfrentar problemas. Sbruzzi (1999) detectou, em particular, dificuldades de cunho financeiro: dos organismos que participaram da sua criação, somente o Senai continuava a contribuir no período em que essa autora realizou a sua pesquisa. Essa carência de recursos financeiros certamente ajuda a explicar a assimetria então observada entre os laboratórios instalados, no que concerne ao grau de atualização dos equipamentos e também à aparente limitação em termos de recursos humanos.

Especialmente problemático, tendo em vista o seu caráter de organismo tecnológico, era o fato de o Centro atuar precariamente tanto em assessoria e transferência tecnológica como em atividades ligadas às inovações, a despeito de algu- 
mas parcerias estabelecidas nos seus primeiros anos. É verdade que, na indústria cerâmica, o conhecimento é amplamente codificado, com inovações de processo basicamente originárias dos fabricantes de máquinas e equipamentos e insumos (países como Itália e Espanha, líderes no setor cerâmico em escala mundial, aparecem como fontes das principais emanações). Entretanto, as inovações de produto, conquanto associadas também às possibilidades oferecidas por maquinário e insumos, envolvem aspectos como design e melhorias diversas na qualidade, e para isso os vínculos estabelecidos localmente com fornecedores e com instituições como o CTCmat devem, ou deveriam, mostrar-se importantes.

Até o final da década de 90, o CTCmat parece ter atuado principalmente em prestação de serviços de laboratório. O quanto isso passou a marcar o sistema local ganhou ilustração na tendência de alguns ceramistas transferirem as suas correspondentes atividades para aquela instituição, com atrofia das próprias capacidades internas. Seja como for, durante muito tempo, o campo de abrangência de tais serviços mostrou-se restrito, inclusive porque esse tipo de vínculo, centrado em procedimentos como análises de matérias-primas e de produtos acabados, não costumava alcançar os fornece- dores de insumos. Como Sbruzzi (1999.) sublinhou, boa parte de tais fornecedores integra estruturas empresariais multinacionais, o que lhes possibilita o aproveitamento de fluxos tecnológicos materializados na própria trama de relações da qual esses estabelecimentos fazem parte, com origem nas matrizes. Naturalmente, isso remete ao problema do grau de inserção do CTCmat no tecido produtivo local. De todo modo, uma avaliação recente constatou a existência de interações merecedoras de realce.

Dentre as parcerias relevantes (...) destaca-se a função exercida (...) em fornecer credenciamento para os produtos acabados, importante requisito para as empresas adentrarem os mercados mais exigentes (Cário e Enderle, 2005, p. 173).

Os atores que integram o cluster prezam o funcionamento dessa instituição, reconhecendo-lhe a importância. Mas o fato de muitas firmas travarem contato com as inovações da indústria cerâmica por conta própria (e mais rapidamente do que o próprio CTCmat), contribuía, no período em que Sbruzzi (1999) levantou os dados, para que a importância do centro como difusor de informações e conhecimento técnico e tecnológico fosse consideravelmente relativizada, já que sua atuação em atividades ligadas às inovações afigurava-se estreita. Mas 
os problemas não se limitavam a isso. As empresas de maior nível tecnológico concediam escassa abertura ao pessoal do CTCmat, certamente na tentativa de proteger segredos diante das possibilidades de imitação amplificadas pela proximidade entre os fabricantes. Essa restrição ao acesso é assinalada como segue no estudo consultado, elaborado antes da conversão da instituição em CTCmat:

$$
\begin{aligned}
& \text { As empresas [mais importantes] não per- } \\
& \text { mitem que técnicos do CTC acompanhem } \\
& \text { os processos, não utilizam os serviços de } \\
& \text { assistência tecnológica [da instituição] e } \\
& \text { evitam trabalhos em parceria para manter } \\
& \text { o segredo industrial. Segundo um técnico } \\
& \text { entrevistado, de uma grande empresa, esta } \\
& \text { prefere resolver internamente seus proble- } \\
& \text { mas ou contar com o apoio de técnicos dos } \\
& \text { fornecedores para não precisar permitir o } \\
& \text { acesso de técnicos do CTC à fábrica e ao } \\
& \text { processo produtivo (Sbruzzi, 1999, p. 87). }
\end{aligned}
$$

\section{2_Vínculos interfirmas}

O final da parte anterior remete ao problema das relações entre as empresas que compõem o cluster cerâmico. Um primeiro aspecto a assinalar é que "verticalização" parece palavra de ordem no interior do referido coletivo de agentes: estudo realizado há alguns anos sublinhou que, na região ceramista do Sul de Santa Catarina, se observa uma articulação ainda incipiente da cadeia produtiva, o que resulta em baixo grau de aproveitamento das vantagens decorrentes da aglomeração industrial (Fabre, 1999, p. 31).

Com efeito, subcontratar era não mais do que uma tímida tendência, a qual, além disso, costumava incidir apenas no fornecimento de matérias-primas. Nos casos em que era registrada, a desverticalização refletia tão-somente uma certa inclinação de algumas empresas maiores para "focalizar" as suas atividades.

O essencial da cooperação interna à área refere-se aos vínculos entre fabricantes de pisos e azulejos e fornecedores de matérias-primas e insumos. Investigação realizada por Campos, Nicolau e Cário (1999) indicou que esse tipo de relação é considerado pelos ceramistas um importante vetor de aprendizagem tecnológica, como também ocorre com a incorporação de capital fixo oriundo do exterior e com as interações implicando o tecido institucional (Tabela 2). De outra parte, aqueles vínculos ocupavam posição de grande destaque nas atividades desenvolvidas pelas empresas de insumos da área, seja no que concerne às vendas, seja no que se refere às parcerias com clientes para o desenvolvimento de produtos. As referidas inter-relações en- 
globavam sobretudo os agentes (colorifícios) que abastecem os ceramistas com fritas, esmaltes e corantes, já que a cooperação nessa escala mostra-se fundamental para a especificação dos pisos e azulejos fabricados, tendo em vista a importância dos referidos insumos. As matérias-primas mais comuns, como caulim e argilas, eram em boa parte supridas por empresas que pertenciam aos próprios grupos cerâmicos (Fabre, 1999).

O que se logrou alcançar com base nas relações entre ceramistas e colorifícios é merecedor de realce, visto que houve repercussão até em matéria de design, um aspecto cada vez mais proeminente no padrão de concorrência do setor cerâmico em termos internacionais. Não é desprovido de significado que os fornecedores de colorifícios disponibilizem localmente serviços idênticos aos que são oferecidos na Europa (Meyer-Stamer, Maggi e Seibel, 2001). Todavia, esse aspecto positivo não deve ensejar generalizações e muito menos otimismo descabido a respeito da cooperação local.

Tabela 2_Aglomerado ceramista Sul-catarinense: formas de desenvolvimento ou incorporação de novas tecnologias pelos ceramistas no final dos anos $\mathbf{9 0}(\%)$

\begin{tabular}{|c|c|c|c|c|c|}
\hline \multirow[b]{2}{*}{ Origem das tecnologias } & \multicolumn{5}{|c|}{ Grau de importância } \\
\hline & $\begin{array}{c}\text { Sem } \\
\text { importância }\end{array}$ & $\begin{array}{c}\text { Pouco } \\
\text { importante }\end{array}$ & Importante & $\begin{array}{c}\text { Muito } \\
\text { importante }\end{array}$ & Total \\
\hline Máquinas compradas no Brasil & 42,8 & 28,6 & 14,3 & 14,3 & 100 \\
\hline Máquinas compradas no exterior & 0 & 0 & 14,3 & 85,7 & 100 \\
\hline Cooperação com fornecedores de equipamentos & 28,6 & 0 & 42,9 & 28,5 & 100 \\
\hline Unidades produtivas da própria empresa & 14,3 & 28,6 & 14,3 & 42,8 & 100 \\
\hline Laboratórios de P\&D das empresas & 14,3 & 28,6 & 14,3 & 42,8 & 100 \\
\hline Cooperação com concorrentes & 100,0 & 0 & 0 & 0 & 100 \\
\hline $\begin{array}{l}\text { Cooperação com instituições (ensino-pesquisa, } \\
\text { de apoio, etc.) }\end{array}$ & 0 & 0 & 71,4 & 28,6 & 100 \\
\hline Licenciamento & 66,6 & 16,7 & 16,7 & 0 & 100 \\
\hline Cooperação com fornecedores de insumos & 0 & 14,2 & 42,9 & 42,9 & 100 \\
\hline
\end{tabular}

Fonte: Campos, Nicolau e Cário (1999). 
De fato, na já aludida pesquisa de Campos, Nicolau e Cário (1999), não foi encontrada uma só empresa, entre os fabricantes de pisos e azulejos e entre os fornecedores de equipamentos, que apontasse a cooperação com concorrentes como um dos veículos da própria aprendizagem tecnológica; entre os fornecedores de insumos, só uma minoria respondeu positivamente. A ausência de cooperação entre os ceramistas é especialmente digna de nota. De acordo com Fabre (1999), o conjunto de fabricantes de pisos e azulejos tem registrado uma acirrada competição, praticamente sem interações sobre assuntos ligados a tecnologia, importação de insumos ou iniciativas conjuntas envolvendo, por exemplo, compra-e-venda e marketing. A conduta dessas empresas quanto ao acesso de técnicos do CTCmat às áreas de produção, assinalada na parte anterior, dá a medida do que se quer realçar.

Esforços conjugados entre os ceramistas são perceptíveis notadamente quando está em jogo a defesa de interesses gerais do setor ou o equacionamento de problemas situados em áreas pré-competitivas, como na formação de mão-deobra. O engajamento dos empresários, dirigido tanto à Unesc quanto ao governo estadual, em torno da criação do assi- nalado curso superior de Tecnólogo em Cerâmica, por exemplo, insere-se nesse tipo de mobilização. A principal ilustração, todavia, diz certamente respeito à ação coletiva direcionada à criação do CTCmat, permeada de negociações longas e de um difícil processo de barganha política. De todo modo, a comparação com outras realidades produtivo-regionais de Santa Catarina sugeriu a alguns observadores que "as empresas do setor cerâmico cooperam mais intensamente do que as de outros setores" (Meyer-Stamer et al., 1997, p. 30). É possível que seja assim, embora a situação captada pelos mencionados estudos de Fabre e Sbruzzi não justifique o otimismo de Meyer-Stamer (1999), para quem a crise que castigou o complexo cerâmico Sul-catarinense foi decisiva para modificar o espírito de rivalidade e individualismo historicamente observado.

Essa crise significou o ponto culminante da difícil trajetória percorrida pelo setor ceramista nas últimas décadas, quando se registrou preocupante contração do mercado interno a reboque das perturbações na construção civil, nos anos 80. Nos 90, a recessão do início da década representou ociosidade do parque cerâmico regional em níveis muito elevados, redundando em multiplicação das demissões. A conjuntura da década 
anterior havia estimulado as empresas a voltar a atenção para o mercado externo, e as tentativas enfeixadas nessa orientação exigiram avanços competitivos alicerçados em reestruturação produtiva, com modernização tecnológica e organizacional. Assim, a passagem para a década de 90 testemunhou investimentos consideráveis na indústria cerâmica catarinense (Locatelli, 1993), refletidos em máquinas e equipamentos oriundos do exterior, introdução ou expansão no uso de robôs, incorporação de sistemas CAD e atualização da gestão da qualidade e da produtividade, com desenvolvimento da estrutura tecnológica nas empresas mais importantes.

Diferenciar produto consistiu em objetivo central do movimento protagonizado. A concorrência de outros fabricantes nacionais (instalados principalmente em São Paulo) incidia, como segue ocorrendo, principalmente nas linhas de produtos mais populares, nas quais os ceramistas Sul-catarinenses enfrentavam mais dificuldades para competir (Cunha, 1997). Desse modo, um significativo esforço de diferenciação foi implementado, visando à penetração em espaços de mercado mais seletivos, freqüentados por consumidores de maior poder aquisitivo, e, simultaneamente, mirando o favorecimen- to das vendas no exterior. Pode-se dizer que o lançamento do grês porcelanato pela Eliane (um dos dois grupos ceramistas mais importantes da região) inscreveu-se em tal estratégia, assim como a tentativa da Cecrisa (o outro dos principais fabricantes de pisos e azulejos) de difundir a marca Portinari, um procedimento que canalizou o principal dos gastos com marketing dessa empresa no período (Sousa, 1998).

Meyer-Stamer (1999) sugere que a inclinação para ação coletiva e cooperação - que esse autor julga ter se tornado realidade localmente nos últimos anos da década passada - dos fabricantes de pisos e azulejos Sul-catarinenses pode ser explicada pela intensidade da crise do setor cerâmico nesse aglomerado. Esse fator teria sido ombreado pelos efeitos (em especial as implicações em termos de aprendizagem) dos contatos mantidos com as firmas italianas em cujas estruturas os empresários da região parecem ter se inspirado para modernizar a produção cerâmica.

a rivalidade feroz e a falta de cooperação (que prevaleciam antes de 1990) levaram algumas firmas à beira da bancarrota e comprometeram a competitividade, na verdade a sobrevivência, do cluster como um todo. Essas experiências mostraram a insustentabilidade do tradicional comportamento não cooperativo. As duas empresas 
maiores estavam envolvidas em uma corrida pela condição de maior produtora de revestimentos cerâmicos nos anos 80 , investindo em novas fábricas e absorvendo firmas menores. Quando as vendas cairam dramaticamente, após 1989/1990, ambas estavam extremamente vulneráveis. Firmas menores informam que as duas grandes eram hostis a qualquer tipo de cooperação no passado. Além disso, as firmas menores procuravam se distanciar das duas maiores, temendo também se transformar em alvos de absorção. Tudo isso mudou depois da crise do final dos anos 80/ início dos 90 - porque não havia mais necessidade [daquele tipo de comportamento] (a saber, necessidade de consolidação), haja vista [inclusive] as intervenções dos credores (que forçaram a saída de familiares da gestão de uma das grandes firmas), $e$ devido à moderação de dois atores chaves, pertencentes a associações locais, que reuniram as grandes firmas no intuito de encontrar solução para a disputa entre elas (Meyer-Stamer, 1999, p. 295-296).

\section{5_Considerações finais}

Conforme assinalado no início do texto, os desafios ao desempenho competitivo observados na atualidade alçaram a capacidade de aprender e inovar à condição de atributo essencial de firmas e instituições. Indicou-se igualmente que, devido aos benefícios derivados da proximidade entre os atores e do favorecimento e incentivo às interações dinâmicas e densas, desenvoltura e sucesso em termos de aprendizagem e inovação apresentam-se facilitados em estruturas produtivas organizadas em escala local-regional. Isso implica admitir que as aglomerações produtivas representam ambientes férteis à cooperação, entre empresas e envolvendo também de instituições, e propiciam dinamismo na aprendizagem e na inovação, processos reconhecidos como complexos e necessariamente coletivos e interativos. De acordo com literatura que repertoria e analisa casos de sucesso, detectados quase sempre no centro do capitalismo mundial, os espaços onde os processos de aprendizagem mostram-se institucionalmente organizados e são acompanhados por efetivo protagonismo inovador desnudam-se como regiões de aprendiragem.

$\mathrm{Na}$ abordagem dos aglomerados têxtil-vestuarista e ceramista do Vale do Itajaí e do Sul de Santa Catarina, respectivamente, a problemática das regiōes de aprendiragem foi utilizada como "chave de leitura”, o que quer dizer inspiração para o direcionamento do olhar analítico, o qual resulta "instruído" por alguns elementos de relevo do referido debate. 
Buscar localmente o "modelo" de região de aprendizagem esboçado na literatura internacional seria empreendimento irremediavelmente fadado à frustração, configurando, além de tudo, carência de perspectiva contextual: conforme discutido com base em estudos que têm chamado a atenção para isso, a própria condição periférica do tipo de ambiente em que tais aglomerações se inscrevem tende a representar barreira ao pleno desenvolvimento quer do potencial de aprendizagem, quer da disseminação do conhecimento, com reflexos na dinâmica inovativa. Assim, o exame das duas aglomerações catarinenses restringiu-se aos aspectos de institucionalização da aprendizagem e interações entre empresas.

Esse ângulo de observação indicou que essas aglomerações, com as particularidades próprias das distintas trajetórias setoriais e regionais, exibem atributos ligados aos próprios tecidos empresariais, aos recursos intangiveis associados ao acúmulo de conhecimentos em nível local e às suas bases institucionais, ativas e com desempenhos multidirecionados. De outra parte, e talvez principalmente (por conta da perspectiva privilegiada no estudo), merece relevo o fato de que a trajetória e o funcionamento desses clusters são permeados por dinâmicas de aprendizagem, o que está longe de surpreender tendo em vista, entre outras coisas, a clara superposição e articulação, em nível local, de "espessos" tecidos empresariais e institucionais. Com efeito, há que registrar, por exemplo, a ocorrência do learning-by-interacting, implicando, no Médio Vale do Itajaí, vínculos sobretudo entre empresas e instituições e, no Sulceramista, vínculos tanto dessa natureza quanto os testemunhados entre empresas situadas em distintos pontos da cadeia produtiva (com profícuo "diálogo" entre ceramistas e colorifícios, acima de tudo). Resultados não negligenciáveis puderam ser observados na esteira dessas interações, com os processos de aprendizagem associados, como indicado no corpo do texto.

Entretanto, o olhar interrogativo lançado às aglomerações mostrou igualmente que as dificuldades existentes no terreno da cooperação entre empresas são significativas. Esse tem sido o caso particularmente no Médio Vale do Itajaí, pois, na área de produção ceramista, como se falou, algumas interações de certo alcance puderam ser percebidas, em que pese a herança de condutas eivadas de rivalidade e individualismo entre os principais agentes do cluster, isto é, os fabricantes de pisos e azulejos. Naturalmente, 
No sentido $\cdots \cdots \cdots$ frase, a expressão é utilizada por Landabaso, Oughton e Morgan (1999). essa tônica de resistência à ação coletiva não contribui - e sim representa obstáculo - para a transferência e a difusão do conhecimento, representando, por conseguinte, limitação aos processos de aprendizagem. Desde logo, estimular e nutrir laços de cooperação há de figurar como objetivo básico a ser perseguido nesses ambientes, merecendo posição de realce em políticas e estratégias de promoção industrial e desenvolvimento local-regional.

Este último aspecto, referente à promoção das atividades produtivas com repercussões em termos de desenvolvimento local-regional, remete à participação irrevogável do setor público. A ação do Estado é, de fato, crucial nos sistemas locais. Segundo Lundvall e Borrás (1997), recaem sobre tal setor as atribuições de despertar a consciência dos agentes sobre a importância das redes de cooperação, de facilitar contatos entre atores, visando desencadear processos de análise sobre assuntos de interesse coletivo, de estimular a articulação entre as firmas, a partir da criação de infra-estrutura que impulsione as iniciativas de colaboração (centros de serviços, por exemplo), e de contribuir financeiramente para o surgimento e a operação das mencionadas redes de cooperação interfirma. De uma forma mais ampla, cabe ao setor público, talvez antes de tudo, a mediação das relações entre os agentes, removendo as dificuldades que podem travar as interações e estimulando a aprendizagem coletiva. Ao agir dessa forma, o governo incorpora um tipo de papel sugestivamente evocado pela expressão "inteligência coletiva". ?

De qualquer modo, é fundamental reconhecer que, em boa medida, as iniciativas de política devem se originar no interior do próprio ambiente alvo das intervenções. Isso não significa postular que impulsos externos são irrelevantes, e sim admitir que é principalmente no nível local-regional que a percepção sobre as necessidades mostra-se bem-sucedida: nessa escala são captadas nuances que geralmente escapam às visões de fora, $\mathrm{o}$ que tende a lubrificar a mobilização em torno de objetivos conjuntos, favorecendo a concretização das ações e dandolhes conseqüência. É nessa escala, por conseguinte, que as medidas de amparo e impulsão à aprendizagem e de fomento à inovação tendem a se revelar mais promissoras. Convém assinalar, de toda maneira, que o ambiente macroeconômico sempre afeta as iniciativas regionais, de uma forma ou de outra, podendo potencializar as medidas implementadas ou, ao contrário, retirar-lhes ou diminuir-lhes a 
eficácia. Em outras palavras, a regulação local representa órbita de governança relevante e privilegiada, mas isso não autoriza expectativas sobre resultados cujas condições situam-se majoritariamente fora do seu horizonte de possibilidades.

No Médio Vale do Itajaí e no "Sulcatarinense ceramista", o (relativamente pouco) que se detectou de movimentos ensaiados com vistas à intensificação dos vínculos no interior dos respectivos sistemas produtivos teve como protagonistas-chaves, no tocante às iniciativas que resultaram nas providências registradas, algumas firmas e as associações de representação/auto-ajuda e coordenação, principalmente as segundas. Motivados por pressões originadas nas transformações macroeconômicas recentes, esses movimentos não refletiram, até onde foi possível perscrutar, qualquer evolução "natural" em escala de cluster e ocorreram sem um envolvimento maior do setor público. Isso estaria indicando, com respeito à promoção de ações coletivas no âmbito local-regional, a necessidade de condutas governamentais de uma outra natureza, mais voltadas, e com eficácia, à articulação dos agentes locais na perspectiva de uma dinamização da estrutura socioprodutiva como um todo.

Um desafio que em quaisquer aglomerações produtivas merece a firme e bem concebida ação política prende-se ao fato de que, a despeito dos atributos que esses ambientes possuem, de uma forma geral, tais aglomerações - incluindo as designadas na literatura internacional como regiōes de aprendiragem - estão longe de se mostrar imunes às adversidades, podendo amargar a deterioração da capacidade produtiva local. Vários podem ser os motivos dessa eventual deterioração, desde a erosão das vantagens incrustadas nos seus principais recursos - a partir de mudanças no ambiente competitivo, por exemplo - ao que se pode chamar de lock-in regional, uma expressão que capta os entraves à evolução futura decorrentes da manutenção prolongada de um mesmo estado de coisas, num "efeito aprisionamento" que dificulta readaptações (Lundvall e Borrás, 1997; Maskell e Malmberg, 1999). Assim, diferentes autores entendem que promover sistemas locais requer, em diferentes circunstâncias, a criação de coalizões de desenvolvimento regional, no marco das quais se possa estender a lógica das parcerias cooperativas que ocorrem em escala de empresa para outros setores da sociedade territorializada. Isso parece especialmente importante nas regiões menos desenvolvidas, cujos sistemas de inovação tendem a ser fragmentados e ostentam 
elos bastante frágeis, um perfil típico de ambientes periféricos.

Em face de ameaças desse gênero, apoiar a intensificação dos processos de aprendizagem e o dinamismo da inovação é tipo de procedimento irrecusavelmente estratégico. Entretanto, as políticas e iniciativas correspondentes devem ser permeadas pelo adequado entendimento da natureza coletiva e interativa de tais processos. $\mathrm{O}$ fomento à colaboração, mediante o estímulo à construção de redes de vínculos cooperativos e/ou o fortalecimento das redes existentes, há de se perfilar como aspecto central de quaisquer medidas. As pequenas e as médias empresas costumam aparecer como agentes que se beneficiam de modo especial de tais políticas, pois os vínculos de cooperação no interior das redes possibilitam-lhes o aproveitamento de economias externas coletivas - no bojo de interligações materializadas em investimentos conjuntos (como na formação de recursos humanos) - e pode favorecer-lhes o posicionamento competitivo perante empresas de maior porte.

Embora quase nada insinue, pelo menos até o presente momento, que o Médio Vale do Itajaí e o "Sul-catarinense ceramista" deparam-se com a deterioração de sua capacidade produtiva, motiva- da pela erosão das vantagens representadas por seus recursos ou devido a algum "efeito aprisionamento" relacionado às respectivas trajetórias setoriais, cabe assinalar, com respeito a essas aglomerações, a necessidade de atenção para as mudanças que a produção têxtil-vestuarista e a produção cerâmica vêm experimentando em escala mundial nas últimas décadas. Essas mudanças abrangem avanços tecnológicos e organizacionais importantes, que lubrificam a inovação em nível de produto e de processo e afetam o padrão de concorrência. Isso tem estimulado um processo de contínuo e marcado upgrading junto a numerosos fabricantes localizados em diferentes países - inclusive, talvez principalmente, na periferia do capitalismo mundial, como no Leste Asiático -, vários dos quais vêm galgando posições importantes na concorrência globalizada. Dificuldades no acompanhamento desse tipo de tendência, resultando em perda de sintonia com a evolução dos mercados, podem vir (a rigor tendem) a resultar em real deterioração das condições locais.

Tendo em conta possíveis ameaças futuras nessa direção, o olhar dirigido ao Médio Vale do Itajaí e ao aglomerado ceramista Sul-catarinense sugere que os governos locais necessitam, eles pró- 
prios, aprender a lidar com as pressões derivadas dos processos em curso em esferas amplas, como a mundial. Quer dizer, vale para os casos tratados no artigo o que Glasmeier (1999) assinalou de uma forma geral, com base na observação de distintas realidades socioprodutivas territorializadas: na economia moderna, a aprendizagem e a inovação são necessidades constatadas também nas instituições, sejam elas privadas, sejam elas públicas. 


\section{Referências bibliográficas}

AUDRETSCH, D. B.; FELDMAN, M. R\&D spillovers and the geography of innovation and production. The American Economic Review, v. 86, n. 3, p. 630-640, June 1996.

BECCATINI, G. Le district marshallien: une notion socio-économique. In: BENKO, G.; LIPIETZ, A. (Dirs.). Les régions qui gagnent. Paris: Presses Universitaires de France, 1992. p. 35-55.

BIANCHI, P. Industrial policy initiatives in support of small and medium-scale industry: impact of changes in industrial structure and integration on SMI clusters. In: SEMINAR ON NEW TRENDS AND CHALLENGES IN INDUSTRIAL POLICY, 1997, Vienna: United Nations Industrial Development Organization.

Mimeografado.

CAMPOS, R. R.; CÁRIO, S. A. F.; NICOLAU, J. A. Arranjo produtivo têxtil-vestuário do Vale do Itajai/SC. Florianópolis: Universidade Federal de Santa Catarina, 2000. (Texto para Discussão, n. 3).

CAMPOS, R. R.; NICOLAU, J. A.; CÁRIO, S. A. F. Processos de aprendizagem tecnológica em sistemas produtivos locais: o caso do cluster $\mathrm{da}$ indústria cerâmica em Santa

Catarina. Florianópolis:

Universidade Federal de Santa

Catarina, 1999. (Texto para

Discussão, n. 10).
CÁRIO, S. A. F.; ENDERLE, R. Arranjo produtivo de cerâmica de revestimento da Região Sul.

Florianópolis:

UFSC/PPDG/Neitec, p. 136-182, out. 2005, (Programa estratégico de desenvolvimento com base na inovação: Relatório Geral).

COOKE, P.; URANGA, M. G.; ETXEBARRIA, G. Regional innovation systems: institutional and organisational dimensions. Research Policy, v. 26, n. 4-5, p. 475-491, 1997.

COURLET, C.; PECQUEUR, B. Les systèmes industriels localisés em France: um nouveau modèle de développement. In: BENKO, G.; LIPIETZ, A. (Dirs.). Les régions qui gagnent. Paris: Presses Universitaires de France, 1992. p. 81-102.

CUNHA, I. J. A indústria catarinense rumo ao novo milenio. Florianópolis:

Fiesc/Sebrae-SC, 1997.

FABRE, A. J. Complexo de revestimentos cerâmicos do sul de Santa Catarina: análise sob enfoque do conceito de cluster ou distrito industrial. 1999. Dissertação (Mestrado em Geografia) Universidade Federal de Santa Catarina, Florianópolis, 1999.

FLORIDA, R. Toward the learning region. Futures, v. 27, n. 5, p. 527-536, 1995.
FORAY, F. The secrets of industry are in the air: industrial cooperation and the organizational dynamics of the innovative firm. Research Policy, v. 20, p. 393-405, 1991.

GAROFOLI, G. Les systèmes de petites entreprises: um cas paradigmatique de développement endogène. In: BENKO, G.; LIPIETZ, A. (Dirs.). Les régions qui gagnent. Paris: Presses Universitaires de France, 1992. p. 57-80.

GLASMEIER, A. K. Territory-based development policy and planning in a learning economy: the case of "real service centers" in industrial districts. European Urban and Regional Studies, v. 6, n. 1, p. 73-84, 1999.

HENSCHEL, R. O setor

têxtil-vestuarista de Brusque diante das mudancas econômicas dos anos 1990: uma abordagem à luz da noção de eficiência coletiva. 2002. Dissertação (Mestrado em Economia) - Universidade Federal de Santa Catarina, Florianópolis, 2002.

HERING, M. L. R. Colonizacão e indústria no Vale do Itajaí: o modelo catarinense de desenvolvimento. Blumenau: Editora da FURB, 1987.
HUDSON, R. "The learning economy, the learning firm and the learning region": a sympathetic critique of the limits to learning. European Urban and Regional Studies, v. 6, n. 1, p. 59-72, 1999.

LANDABASO, M.; OUGHTON, C.; MORGAN, K. The regional innovation policy in the beginning of the XXI Century. In: VIII SEMINARIO LATINO-IBEROAMERICANO DE GESTIÓN

TECNOLÓGICA - ALTEC'99, 1999, Valencia (Espanha). Resúmenes y Ponencias... Valencia: Universidad Politécnica de Valencia, 1999. p. 459-495

LINS, H. N. Clusters industriais, competitividade e desenvolvimento regional: $\mathrm{da}$ experiência à necessidade de promoção. Estudos Econômicos, v. 30, n. 2, p. 233-265, 2000a.

LINS, H. N . Reestruturacão industrial em Santa Catarina: pequenas e médias empresas têxteis e vestuaristas catarinenses perante os desafios dos anos 90 . Florianópolis: Editora da UFSC, $2000 \mathrm{~b}$.

LINS, H. N. Chips \& sweating system: metáforas para a reestruturação produtiva. Ensaios FEE, v. 24, n. 1, p. 151-176, 2003. LOCATELLI, C. As empresas que investem na crise. Relatório da Gazeta Mercantil - Santa Catarina, p. 2 e 5 , ago. 1993. 
LUNDVALL, B.; BORRÁS, S. The globalising learning economy: implications for innovation policy. Brussels: European Commission, Directorate General XII - Science, Research \& Development, 1997.

MARSHALL, A. Principles of economics: an introductory volume. $8^{\text {th }}$ ed. London: Macmillan, 1979.

MARTINEZ, C. Longe dos chinelos. Gazeta Mercantil Santa Catarina - Balanço Anual, p. 28-30, set. 1998.

MARX, K. Le capital. Livre I. Moscou: Editions du Progrès, 1982 MASKELL, P.; MALMBERG, A. Localised learning and industrial competitiveness. Cambridge Journal of Economics, v. 23, p. 167-185, 1999.

MEYER-STAMER, J. Regional and local locational policy: what can we learn from the ceramics and textiles/clothing clusters of Santa Catarina, Brasil?. In: CLUSTERS E SISTEMAS LOCAIS DE INOVACÃO: ESTUDOS DE CASO E AVALIACÃO DA REGIÃO DE CAMPINAS, Campinas, 1999 Anais... Campinas: Unicamp, 1999, p. 286-308.

MEYER-STAMER, J. et al. Competitividade sistêmica da indústria catarinense. Florianópolis: Instituto Euvaldi Lodi de Santa Catarina, 1997.
MEYER-STAMER, J.; MAGGI, C.; SEIBEL, S. Cadeia de valor global do setor cerâmico: um estudo comparativo dos clusters de Sassuolo, Castellón e Criciúma. Florianópolis: Instituto Euvaldo Lodi de Santa Catarina/IDS/ Inef/ Finep/VW, ago. 2001.

MORGAN, K. The learning region: institutions, innovation and regional renewal. Regional Studies, v. 31, n. 5, p. 491-503, 1997.

NADVI, K.; SCHMITZ, H.

Industrial clusters in less developed countries: review of experiences and research agenda. Brighton: University of Sussex, Institute of Development Studies, Jan. 1994 (Discussion Paper, n. 339) KOSCHATZKY, K. Firm innovation and region: the role of space in innovation processes. International Journal of Innovation Management, v. 2, n. 4, p. 383-408, Dec. 1998.

ROCCA, G. A. D. Avaliacão das instituicōes de pesquisas tecnológicas no setor têxtil-vestuário do Vale do Itajaí - SC. 2003. Dissertação (Mestrado em Economia) Universidade Federal de Santa Catarina, Florianópolis, 2003.

SANTOS, F.; CROCCO, M.; JAYME Jr., F. G. Knowledge externalities and growth in peripheral regions: introductory notes. Belo Horizonte: UFMG/ Cedeplar, dez. 2005. (Texto para Discussão, n. 278)
SANTOS, F.; CROCCO, M.; LEMOS, M. B. Arranjos e sistemas produtivos locais em "espaços industriais" periféricos: estudo comparativo de dois casos brasileiros. Revista de Economia Contemporânea, Rio de Janeiro, v. 6, n. 2, p. 147-180, jul./dez. 2002.

SBRUZZI, L. Centro de Tecnologia em Cerâmica: um estudo de caso sobre cooperação Universidadeempresa. 1999. Dissertação

(Mestrado em Economia) Universidade Federal de Santa Catarina, Florianópolis, 1999.

SCHMITZ, H. Collective efficiency: growth path for small-scale industry. The Journal of Development Studies, v. 31, n. 4 , p. 529-566, Apr. 1995.

SCHMITZ, H. Responding to global competitive pressure: local co-operation and upgrading in the Sinos Valley, Brazil. Brighton: Institute of Development Studies, Dec. 1998. (Working Paper, n. 82).

SCHUMPETER, J. A. Teoria do desenvolvimento econômico. 3. ed. São Paulo: Nova Cultural, 1988.

(Os Economistas).

SOUSA, P. H. Cecrisa centra foco nas Américas. Gazeta Mercantil Latinoamericana, p. 20 16-22 nov. 1998

STORPER, M. The resurgence of regional economies, ten years later: the region as a nexus of untraded interdependencies. European Urban and Regional Studies, v. 2, n. 3 , p. 191-221, 1995.
SWEENEY, G. National innovation policy or a regional innovation culture. Working Papers in European Industrial Policy, European Network on Industrial Policy, n. 1, May 1995.

TERCEIRIZAÇÃO é uma armadilha. Força Operária,

Blumenau, Informativo do Sindicato dos Trabalhadores nas Indústrias de Fiação e Tecelagem de Blumenau, ano VIII, n. 69, p. 1, ago. $1997,1^{\text {a }}$ quinzena. TOMIO, F. R. de L. Organização coletiva e representacão de interesses do empresariado industrial têxtil de Blumenau - SC: a atuação da ACIB e do Sintex em um espaço político-institucional democrático (1985-1994). 1995. Dissertação (Mestrado em Sociologia Política) - Universidade Federal de Santa Catarina, Florianópolis, 1995

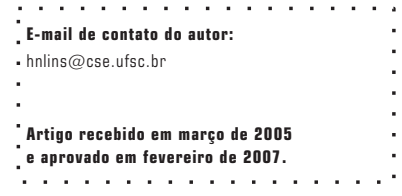

